\title{
Obituaries
}

Obituaries should be submitted by email to Kate Maynard at k.maynard@nature.com.

All submitted obituaries should be 350 words maximum in length (apart from obituaries for past presidents of the BDA

where the length should be 700-800 words).

Content of the obituary is down to the individual author, and the approval of the family should be given for the obituary prior

to submission to the $B D J$.

\section{PETER LENNY}

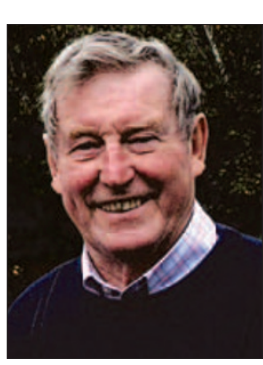

A most admirable quality some people have is the ability to engage with all they meet as an equal, devote time to them and genuinely be interested in them and their welfare no matter what circumstance, age, status or background.

Peter Lenny (13 April 1930 - 29 October 2010) had this gift and will be remembered as 'one of life's true gentlemen'.

Born in Cookstown, Co Tyrone, Peter graduated from the National University of Ireland, Dublin in 1958. After working in Taunton and London, Peter returned to his home town to set up practice in 1960.

Peter dedicated his working life to caring for the dental health of the local community. He maintained a keen interest in postgraduate learning and was one of the leading dentists in the province in the provision of sedation and general anaesthesia through SAAD. An excellent clinician, he gave valuable guidance and example as a VT trainer and Principal to all those who worked with him in his practice. Peter was a lifelong member of the BDA and served on many dental committees including LDC as chairman. Peter retired in 1992 when his eldest son, Mark Lenny BDS, QUB (1986), took over the practice.

A talented sportsman, Peter participated in many sports and represented his county in Gaelic football. He was a member of Killymoon Golf Club for over 50 years and a keen supporter of the BDA NI golf society. The lefthander's pleasurable company both on and off the course will be missed by all his fellow players.
In retirement, Peter and Angela pursued their gardening passion creating a beautiful and relaxing environment around their home which Peter enjoyed working in until his last day.

The latter years of Peter's life he devoted to caring for his beloved wife Angela, missing her profoundly when she passed away on 4 March 2010.

The large congregation made up of family and friends, dental colleagues and patients at his funeral heard the parish priest reflect on his 'healing hands' and 'caring eyes'. All will remember fondly his sense of humour, his gentle calmness and his winning smile.

A devoted family man, Peter is survived by his four sons Mark, John, Michael and Rory.

PML

\section{WENDY BRAZENALL}

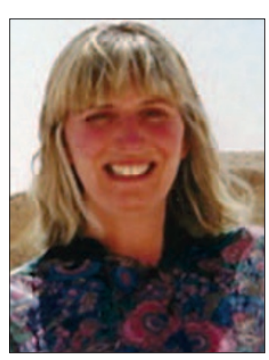

Catherine Wendy Firth was born in York on 29 0ctober 1950. Wendy's favourite subjects during her school years were always science and biology, and she went on to

study biochemistry at Dundee University where she met Bob Brazenall.

After graduating, Wendy worked in cancer research in Edinburgh, until she and Bob were married in York in July 1973. She returned to Dundee to train as a teacher and worked for a year in Logie High School, which was in one of the poorest areas of Dundee - a real challenge for a young teacher.

Bob qualified as a dentist in June 1975 and he and Wendy moved south to England. They initially settled in Swindon, where Wendy worked at the Defence Academy at Shrivenham. She was part of a team who designed training for local authorities to deal with nuclear, biological and chemical incidents around the UK. Her nickname was 'War Games Wendy!'

In 1976 Wendy and Bob moved to Eltham, where Bob opened his own practice and Wendy began her dental training at Guy's Hospital in London. She graduated, with honours, in June 1981.

In 1982 they moved to Devon, where 'Lyndhurst' in Honiton High Street was their dental practice and family home for 22 years.

Wendy had three children - Ben in 1979, Emily in 1982 and Robin in 1986. She juggled the challenges of a busy working life and a growing family, until she retired from dentistry in 1989 , when she could no longer work due to the effects of multiple sclerosis (MS).

In March 2004 Wendy's MS had progressed so that she required full time, professional care and in 2005 she became resident at Lucerne House in Exeter. Here, she was well cared for and still able to be involved in the lives of her family, with regular visits from Bob and the children, and her sister, Carol. There were many outings too, from children's graduations to trips to the beach, from Christmas days to Sunday roasts at home. Wendy was also well enough to be at Ben's wedding to Caroline in September last year and to celebrate her sixtieth birthday in 0ctober with a family meal at the pub.

Wendy's condition continued to deteriorate, until on 30 March this year she was admitted to the Royal Devon \& Exeter hospital with pneumonia, and on 4 April she passed away peacefully.

R. W. C. Brazenall 